INTERNATIONAL JOURN AL OF RESEARCHES IN BIOSCIENCES, AGRICULTURE AND TECHNOLOGY (c) VISHWASHANTI MULTIPURPOSE SOCIETY (G lobal Peace Multipurpose Society) R. No. MH-659/13 (N) www.vmsindia.org

\title{
EFFECT OF ETHYL METHANE SULPHONATE (EMS) ON SEED GERMINATION AND SEEDLING INJURY IN CHICKPEA (CICER ARIETINUM L.)
}

\author{
Pooja Shinde and A. B. Sagade \\ Jijamata college of science and Arts Bhende B.K., Tal. Newasa
}

\begin{abstract}
The effect of Ethyl Methane Sulphonate (EMS) was studied on seed germination and seeding injury in Chickpe a (Cicer arietinum L.) Var. Virat. In this investigation the seeds of the var. Virat were treated by different concentrations of the EMS $(12 \mathrm{mM}, 16 \mathrm{mM}$ and $20 \mathrm{mM})$. The percentages of seed germination were studied on the $7^{\text {th }}$ day, the seed ge rmination was analyze $d$ and the percent seed germination was calculated. Seedling height was recorded on the $10^{\text {th }}$ day only in the germinating seeds. Reduction in the mean seedling length of the treated seedling as compared to the control was regarded as seedling injury and expressed as percentage. Result showed that the percentage of seed germination decreased and seedling injury increased with increasing concentrations of EMS.
\end{abstract}

Keywords: Chickpea, EMS, seed germination, seedling Injury

\section{Introduction}

Chickpea (Cicer arietinum L.) is an important pulse crop widely grown in Indian subcontinent. It is valuable source of dietary protein, In spite of its nutritional importance; the yield of chickpea did not witness much appreciation during the past decade (Barshile etal., 2006). It has been argued that one of the reasons for failure to achieve break through in productivity of chickpea is lack of its genetic variability. Genetic variability is the most essential prerequisite for any successful crop improvement programme as it provides a spectrum of variants for an effective selection process, (Jahagirdar etal., 2005). For any mutation programme, selection of effective and mutagen (s) is very essential to recover higher frequency of desirable mutations, (Solanki and sharma, 2003). A number of mutagens are widely employed to induce genetic variability in plants. Ethyl Methane Sulphonate (EMS) is a well potential mutagen, widely employed in induction of genetic variability, it is an alkyl ting agent and induce high frequencies of base pair substitutions. Present investigation was carried out to see the mutagenic effects of EMS in the variety Virat of the chickpea.

\section{Material and Methods}

Germplasms of the Cickpea cultivar, Virat used in the present investigation was procured from Mahatma Phule Agricultural University, Rahuri (Maharashtra, India). Pilot experiments were conducted to determine suitable concentrations and duration of treatment of the mutagens, for the cultivar. From such experiments it was established that concentrations of $12 \mathrm{mM}, 16 \mathrm{mM}$ and $20 \mathrm{mM}$ of
EMS a duration of 8 hours are best suitable mutagenic treatments for this cultivars. Seeds, presoaked in distilled water for 6 hours, were treated with the above-mentioned concentrations of chemical mutagens for 6 hours at $25 \pm 2^{\circ} \mathrm{C}$ with intermediate shaking. After treatment, the chemical was drained off and seeds were thoroughly washed in a running tap water for an hour, the seeds soaked in distilled water served as control. The treated and control seeds were blotted and kept for germination in three replications on the moist seed ge rminating paper in petri-plates.

\section{Results and Discussion}

Data obtained on effect of different concentrations of EMS on mean percentage of seed ge rmination and percentage seedling injury in control and EMS (Mutagen) treated Chickpea cultivar was observed after $7^{\text {th }}$ day and $10^{\text {th }}$ day respectively is presented in the table -1 .

\section{Percent seed germination-}

From the observations (Table-1) it is evident that the percentage seed germination in the Var. Virat of the Chickpea subjected to the treatment of different concentrations of the EMS than those of their respective control. it is clearly indicates that the mutagens have exerted an inhibitory effect on seed germination. Similar inhibitory effect on seed germination by the mutagens has been reported earlier by Barshile et al., (2006) in chickpea. The percentage of seed ge rmination was $100 \%$ in control. Seeds subjected to the treatment with EMS, the percent seed germination decreased from $100 \%$ to $69 \%$ in $12 \mathrm{mM}$, to $53 \%$ in $16 \mathrm{mM}$ and $45 \%$ in 20mM. $50 \%$ decrease in percent seed 
ge rmination was observed with $16 \mathrm{mM}$ EMS. So this concentration of EMS was adjudged as LD50. The reduction in germination may be due to genetic and physiological processes inhibited by the mutagen (EMS) resulting in cell maturity . Seedling Injury-

Seedling injury was measured as reduction in the height of the mutagen treated seedling as compared to the height of the 10 days old control seedlings. data on the effect of EMS on seedling height on the Var. Virat is presented in the Table-1. From the data it is clear that 11 the treatments showed clear inhibitory effect on the height of the seedlings. Maximum seedling injury (41.20\%) was observed with higher concentration $(20 \mathrm{mM}$ EMS) dose of the mutagen. Similar increase in seedling injury with increased concentrations of mutagens has been reported by Toker and Cagirgan (2004) in Chickpea. According to Markeen et al., (2007) reduction in seedling growth with higher dose may be due to the gross injury caused at cellular level either due to gene controlled biochemical process or acute chro moso mal aberrations or both.

From the above result it can be concluded that EMS is capable of inducing damage at cellular level and is capable of inducing mutations in the cultivar Virat of chickpea.

Table. 1. Effect of EMS on Seed germination and Seedling injury in the Variety Virat of the Chickpea

\begin{tabular}{l|ll|l|l|}
\hline $\begin{array}{l}\text { EMS/ } \\
\text { Contr } \\
\text { ol }\end{array}$ & $\begin{array}{l}\text { Treatmen } \\
\text { ts }\end{array}$ & $\begin{array}{l}\text { \%Seed } \\
\text { ge rminati } \\
\text { on }\end{array}$ & $\begin{array}{l}\text { Mean } \\
\text { Seedlin } \\
\text { g } \\
\text { height } \\
\text { (cm) }\end{array}$ & $\begin{array}{l}\text { Seedlin } \\
\text { Injury } \\
\text { Injey }\end{array}$ \\
\hline $\begin{array}{l}\text { Contr } \\
\text { ol }\end{array}$ & -- & 100 & 11.60 & -- \\
\hline \multirow{2}{*}{ EMS } & $12 \mathrm{mM}$ & 69 & 10.73 & 7.5 \\
\cline { 2 - 6 } & $16 \mathrm{mM}$ & 53 & 7.41 & 36.12 \\
\cline { 2 - 6 } & $20 \mathrm{mM}$ & 45 & 6.82 & 41.20 \\
\hline
\end{tabular}

\section{References}

Barshile, J. D., Auti, S. G., Dalve, S. C. and Apparao, B. J., (2006) Mutagenic Sensitivity Studies in Chickpea Employing SA, EMS and Gamma rays . Indian Journal of Pulses Research, 19 (1): 43-46.

Jahagird ar, J. E., Katare, N. B. and Sude wad, S. M., (2005) Biparental Mating : A tool for Creation of Genetic Variability in Chickpea. Indian Journal of Pulses Resurch, 18: 12-13.

Markeen Kouser, G. Suresh Babu and G. R. Lavanya., (2007) Effect of Mutagenes is on $\mathrm{M}_{1}$ population in Urdbean. Journal of Food Legumes 20 (1): 109-110.

Solanki, I. S. and Sharma, B., (2003) Morphological Mutations Induced by Gamma Rays, Ethyl Inine and N-Nitroso-n-Ethyl Urea in Lentil. J. Genet., 53 (2): 168-173.

Toker, C. and Cagirgan, M. I., (2004) Spectrum and Frequency of Induced Mutations in Chickpea. ICPN, 11:8-10. 